\title{
The growth hormone-binding protein in rat serum is an alternatively spliced form of the rat growth hormone receptor
}

\author{
William R. Baumbach, Deborah L. Horner, and John S. Logan ${ }^{1,2}$ \\ Molecular and Cellular Biology Group, American Cyanamid, Princeton, New Jersey 08540 USA
}

A cDNA clone isolated from rat liver was demonstrated to encode a soluble, secreted growth hormone (GH)-
binding protein consistent with the properties of the newly discovered serum GH-binding protein. The protein
coding region of this cDNA was identical in sequence to the extracellular domain of the rat liver GH receptor
up to three amino acids before the putative transmembrane domain. At this point, an additional 17 amino acids
were encoded in the GH-binding protein before a stop codon was encountered. This cDNA clone was shown to
be representative of the structure of the mRNA present in rat liver. These results suggest that the mechanism
for production of the rat serum GH-binding protein is by alternative splicing of the gene for the rat GH receptor.

[Key Words: Growth hormone; receptor; binding protein]

Received April 27, 1989; revised version accepted June 7, 1989.

Growth hormone $(\mathrm{GH})$ is a polypeptide secreted by the anterior pituitary that acts through specific high-affinity cell-surface receptors located primarily in the liver (Hughes and Frieson 1985). Recently a specific high-affinity protein that binds $\mathrm{GH}$ has been identified in serum (Ymer and Herington 1985; Baumann et al. 1986; Herington et al. 1986). This serum GH-binding protein has a close structural relationship to the $\mathrm{GH}$ receptor present on the surface of cells. Genetic, immunological, and biochemical data suggest colinearity and identity between the extracellular domain of the GH receptor and the GH-binding protein (Eshet et al. 1985; Barnard and Waters 1986; Baumann et al. 1987; Daughaday and Trivedi 1987; Leung et al. 1987; Baumann and Shaw 1988; Spencer et al. 1988). It has been proposed that the $\mathrm{GH}$-binding protein is produced by proteolytic cleavage of the GH receptor (Leung et al. 1987; Spencer et al. 1988; Trivedi and Daughaday 1988).

We now report the isolation and characterization of two classes of cDNA clones, both of which encode proteins that bind GH in vitro. One class encodes a membrane-bound protein, which is the $\mathrm{GH}$ receptor. The other class of cDNA clones encodes a soluble secreted protein that contains the same putative $\mathrm{GH}$-binding region but lacks the transmembrane and intracellular domains. These regions are replaced with a 17-amino-acid hydrophilic segment that is followed by a unique 3 '-untranslated region. The data suggest that the serum GHbinding protein in rats is likely to be an alternatively spliced form of the GH receptor.

\footnotetext{
'Corresponding author.

${ }^{2}$ Present address: Embryogen, Princeton Forrestal Center, Princeton, New Jersey 08540 USA.
}

\section{Results \\ Isolation and characterization of GH receptor and GH- binding protein $c D N A s$}

To isolate clones that encode the rat $\mathrm{GH}$ receptor, a rat liver cDNA library was screened with two oligonucleotide probes and a fragment of a rabbit $\mathrm{GH}$ receptor cDNA. On the basis of restriction mapping and preliminary DNA sequence analysis, the clones could be separated into two classes. Two clones, RatR1 and RatBP1, as representatives of each class, were sequenced completely. Figure 1 shows the nucleotide sequence and the predicted amino acid sequence of both RatR 1 and RatBP1 as well as a comparison of these sequences in the region of divergence. The longest open reading frame in RatR1 contains 638 amino acids and encodes a protein with the known structural properties of the GH receptor. The hydrophobicity profile (Fig. 2) predicts a signal sequence located from amino acid 1 to amino acid 17 and a single transmembrane domain located from amino acid 266 to amino acid 289. Homology comparisons at the amino acid level between this putative rat $\mathrm{GH}$ receptor and the rabbit and human $\mathrm{GH}$ receptors indicate $73.8 \%$ and $68.9 \%$ identity, respectively. Figure 1 shows the nucleotide sequence and predicted amino acid sequence of RatBP1. The longest open reading frame contains 279 amino acids. RatBPl is identical with RatR1 in nucleotide sequence up to amino acid 262. At this point, the sequences diverge and in place of the $\mathrm{GH}$ receptor hydrophobic transmembrane domain there is a unique 17-amino-acid hydrophilic region (Fig. 2). Therefore, it is likely this gene product would be secreted from cells and not anchored in the membrane. On the basis of these data, RatR1 encodes the rat liver GH receptor and 
RatBP1 encodes a soluble secreted form of that receptor consistent with the properties of the GH-binding protein found in serum.

Also shown in Figure 1 is the sequence of RatBP2 that diverges from RatBPl in the $5^{\prime}$-noncoding region. This divergence could represent alternative splicing at the $5^{\prime}$ end of the gene, alternative transcription start sites, or a combination of both. A similar situation with alternative $5^{\prime}$-noncoding regions exists in rabbit $\mathrm{GH}$ receptor clones (Leung et al. 1987).

\section{Structure of the mRNA in rat liver}

To determine whether these cDNAs represent mRNA species present in vivo, cytoplasmic poly $(\mathrm{A})^{+}$RNA was prepared from rat liver and subjected to Northern analysis (Fig. 3A). Three probes were used. Probe $A$ is unique to the $\mathrm{GH}$ receptor and corresponds to its intracellular domain. Probe B corresponds to the extracellular domain of the GH receptor and, therefore, is present in both the $\mathrm{GH}$ receptor and the GH-binding protein. Probe $\mathrm{C}$ corresponds to the unique 17 amino acids and the $3^{\prime}$-nontranslated region of the GH-binding protein cDNAs. Probe A recognizes a 4.75-kb mRNA, and probe $B$ recognizes a 4.75- and 1.2-kb mRNA. Probe $C$ recognizes the $1.2-\mathrm{kb}$ mRNA species. These results indicate that the GH-binding protein cDNAs are represented by a $1.2-\mathrm{kb}$ mRNA and that the GH receptor $\mathrm{CDNAs}$ are represented by a $4.75-\mathrm{kb}$ mRNA. It is likely that RatBP1 and RatBP2 are full-length copies of the 1.2-kb mRNA. Although no poly(A) sequence is present in these cDNAs, the existence of the sequence AATAAA, a signal for polyadenylation (Birnstiel et al. 1985) at the $3^{\prime}$ end of RatBP1 is consistent with this hypothesis. Both males and females contain the same mRNAs in the same ratio, although females reproducibly have slightly elevated levels (Fig. 3A). This observation supports previously published quantitations of GH-binding sites in male versus female rat liver (Maes et al. 1983).

To establish at the nucleotide level the structure of $\mathrm{GH}$ receptor and GH-binding protein mRNAs, S1 nuclease mapping was performed with $3^{\prime}$-end-labeled probes (Fig. 3B). Probe BP is $3^{\prime}$-end-labeled at the BamHI site at position 501 and extends to the extreme $3^{\prime}$ end of

Figure 1. Nucleotide sequence and deduced amino acid sequence of the rat $\mathrm{GH}$ receptor and serum GH-binding protein. The nucleotide sequence and deduced amino acid sequence for the rat GH receptor cDNA clone, Rat $\mathrm{R} 1$, is shown. The nucleotide sequence is numbered beginning with the $\mathrm{A}$ of the first methionine of the longest open reading frame. A comparison of the nucleotide sequence and deduced amino acid sequence of the GH receptor cDNA clone (RatR1) and the serum GHbinding protein $\mathrm{CDNA}$ clone (RatBP1) surrounding the region of divergence is presented. (Arrow) Point of divergence; $(R)$ sequence of the GH receptor; $(B P)$ sequence of the serum $\mathrm{GH}$ binding protein. The signal sequence is shown in boldface print. The shading highlights the putative transmembrane domain. The open box highlights 17-amino-acid residues present at the carboxyl terminus of the binding protein that are not present in the GH receptor. Also shown is a comparison of the $5^{\prime}$-nontranslated region from RatRl and two rat $\mathrm{GH}$-binding protein cDNAs, RatBP1 and RatBP2.
RatBP1. Probe GHR is $3^{\prime}$-end-labeled at the same $B a m H I$ site and extends to the BgIII site at position 936 in RatR1. Thus, both probes have 288 nucleotides in common, extending from the BamHI site to position 787 , after which the receptor and binding protein clones diverge. Each probe was subjected to S1 nuclease mapping by use of female rat liver poly $(\mathrm{A})^{+}$RNA. Probe GHR protected two bands, corresponding to a GH receptor mRNA (443 nucleotides) and a GH-binding protein mRNA (288 nucleotides). The doublet observed at position 288 in Figure 3B (lane d) probably represents incomplete digestion of the GHR probe, but the possibility of heterogeneity in binding protein mRNA cannot be ruled out. However, four independent binding protein

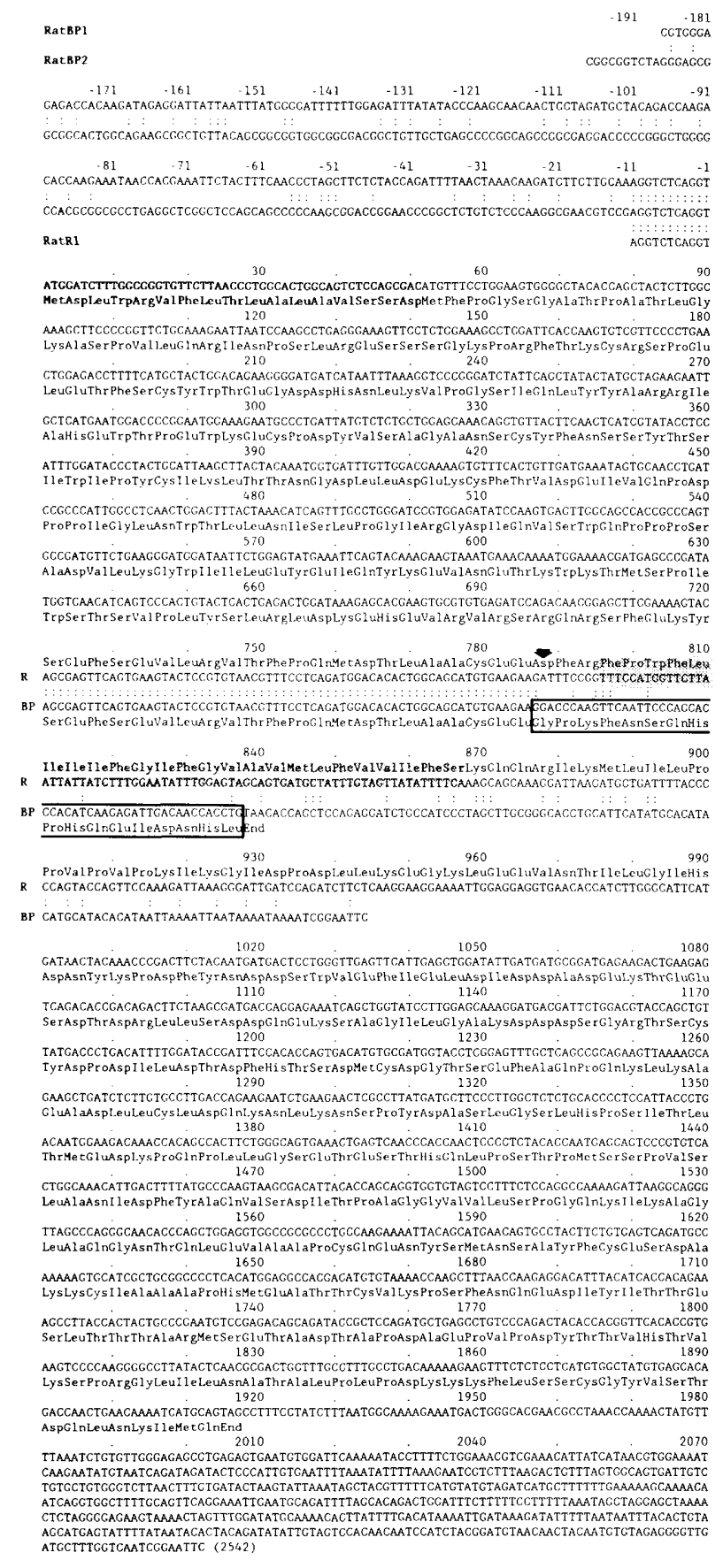




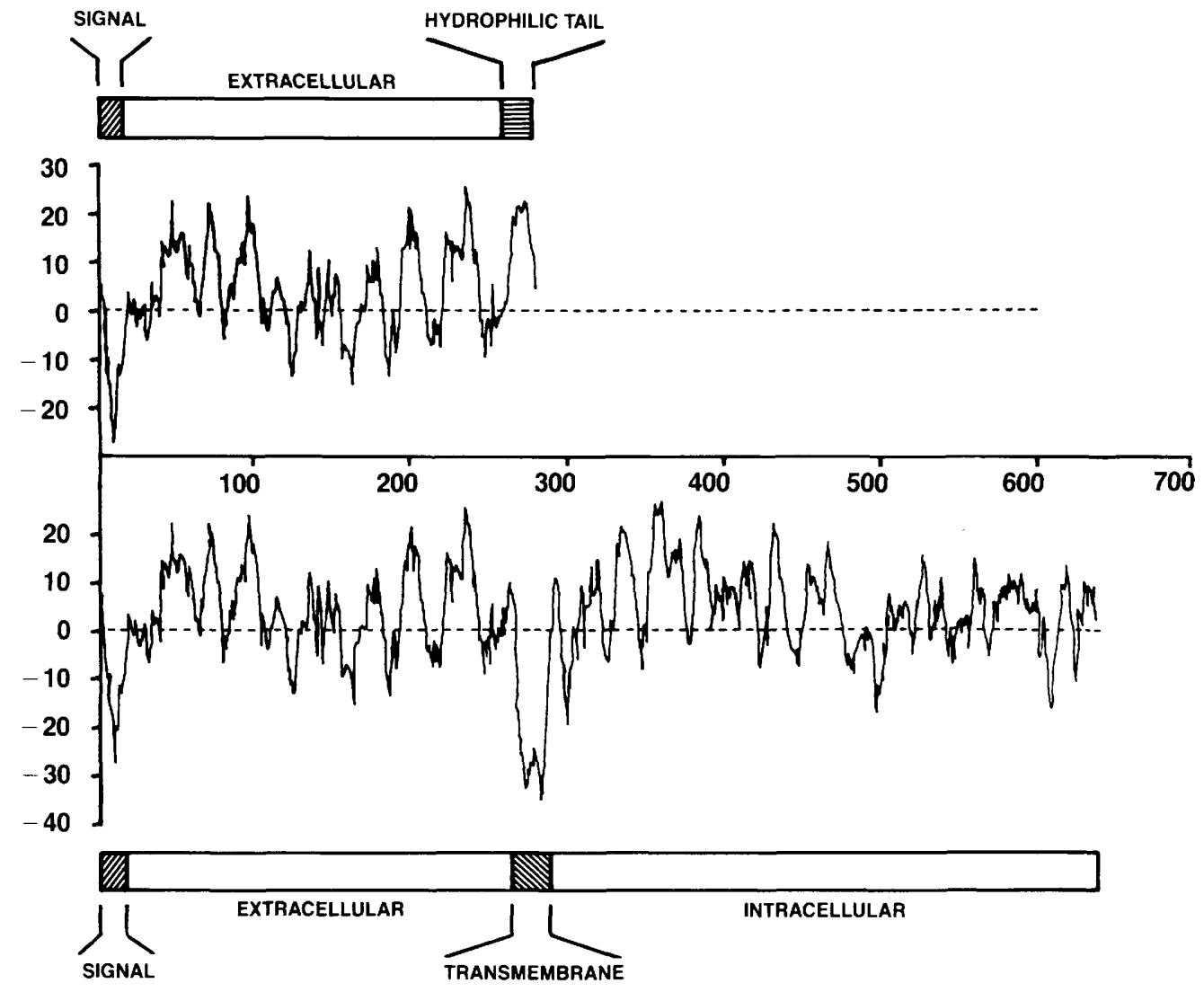

Figure 2. Schematic of the rat GH receptor and the rat serum GH-binding protein. The hydropathy plot is from the method of Kyte and Doolittle (1982) with a window of 10 residues.

cDNA clones were sequenced through this region and found to be identical, which suggests that mRNA heterogeneity is unlikely to be the case. Probe BP protected two bands also. The 447-nucleotide band corresponds to a GH-binding protein mRNA and the 288-nucleotide band corresponds to a GH receptor mRNA. These data show that the RatR1 and RatBP1 cDNAs represent two distinct mRNA species expressed in rat liver.

\section{Expression of GH receptor and GH-binding protein} cDNAs in COS-7 cells

The ligand binding properties and expected physical location of the receptor and binding protein encoded by RatR1 and RatBP1, respectively, were determined by expression in eukaryotic cells. The cDNAs were subcloned into the expression vector pSVL which initiates transcription from the SV40 late promoter and contains the SV40 origin of replication (Templeton and Eckhart 1984). These plasmids were transfected into COS-7 cells (Gluzman 1981). At 3 days post-transfection, the medium and the cells were assayed for binding of ${ }^{125}$ I-labeled bovine GH in the absence and presence of unlabeled bovine $\mathrm{GH}$ to determine specific binding (Table 1). As predicted, essentially all of the RatBP1binding activity $(96 \%)$ was found in the medium. In the case of RatR1, the majority of the specific binding activity was associated with whole cells. The apparently high level $(23 \%)$ of binding activity seen in the medium varied among experiments from undectable to $28 \%$ and probably reflected the release of membrane-bound receptors into the medium through cell lysis. Consistent with this hypothesis is the observation that this complex was larger, as determined by Sephacryl S- 200 chromatography, than the GH-binding protein complex /data not shown). Cross-linking SDS-PAGE studies showed that the GH-binding protein complex was identical in size to the endogenous rat serum GH-binding protein complex (data not shown). Kinetic analysis of the data (Fig. 4; see Materials and methods for details) indicated that the binding was saturable with a dissociation constant $\left\langle K_{d}\right)$ of $0.51 \mathrm{nM}$ for the putative $\mathrm{GH}$ receptor (RatR1) and $0.41 \mathrm{~nm}$ for the putative GH-binding protein (RatBP1). These values are within the range of published constants of bovine $\mathrm{GH}$ binding to rat liver receptors (Maes et al. 1983 and references therein).

\section{Discussion}

A novel cDNA has been cloned from rat liver that encodes a soluble, secreted GH-binding protein. This protein is likely to be the serum GH-binding protein and is identical in sequence to the $\mathrm{GH}$ receptor for the first 262 amino acids but then contains an additional 17 amino acids not present in the GH receptor. The identity in DNA sequence indicates that alternative splicing of the $\mathrm{GH}$ receptor gene is the mechanism of production of the GH-binding protein rather than the existence of two closely related genes. A recent publication (Smith et al. 

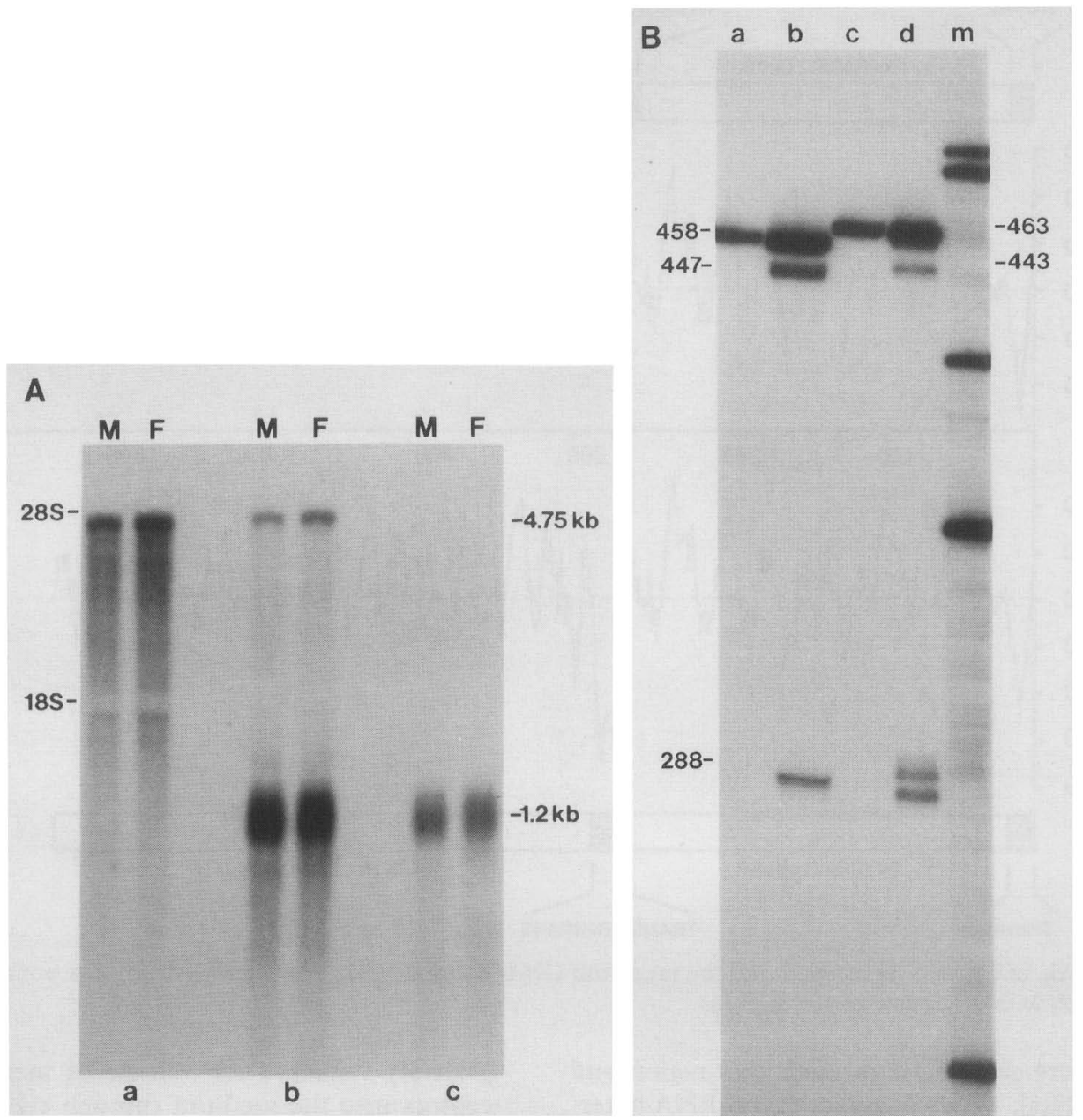

Figure 3. Structure of the mRNA in rat liver. $(A)$ Northern analysis. Each lane contains $3 \mu \mathrm{g}$ of liver poly $(\mathrm{A}))^{+} \mathrm{RNA}$ from adult male $(M)$ and female $(F)$ Sprague Dawley rats. The positions of $28 \mathrm{~S}$ and 18S RNA and the sizes of the hybridizing species are indicated. Lanes are hybridized with probe A (lanes $a$ ), probe B (lanes $b)$, or probe C (lanes $c)$. $(B)$ S1 nuclease analysis. (Lanes $a$ and $b) 3^{\prime}$-end-labeled BP probe; (lanes $c$ and $d$ ) 3'-end-labeled GH receptor probe; (lanes $a$ and $c$ ) no added mRNA; (lanes $b$ and $d) 3 \mu g$ per lane of liver poly(A) ${ }^{+}$ RNA from female Sprague Dawley rats; (lane $\mathrm{m}$ ) end-labeled HpaII restriction fragments of pUC13 DNA. Sizes are given for undigested (reannealed) probes [458 (BP) and $463(\mathrm{R})$ ], full-length protected fragments [447 (BP) and $443(\mathrm{R})]$ and protected fragments representing sequences common to both probes (288).

1988) has confirmed that two mRNAs homologous to the rabbit GH receptor cDNA are present in mouse liver. However, no data were presented on the structure of these mRNAs. Previous evidence from human and rabbit studies has suggested that the GH-binding protein is a proteolytically cleaved form of the receptor (Leung et al. 1987; Spencer et al. 1988; Trivedi and Daughaday 1988). A more detailed investigation of the structure of mRNAs in these species is required to resolve this situation.

The function of the GH-binding protein in serum is unknown. It may function as a reservoir for $\mathrm{GH}$ in serum, and as such, it has been shown to increase the half-life of $\mathrm{GH}$ and to modify its distribution within the body (Baumann et al. 1987). However, the identification of the GH-binding protein as a distinct molecular genetic entity and not necessarily as a proteolytic cleavage product of the GH receptor implies that the level of the two species can be regulated separately. This suggests a variety of possible functions. For instance, GH-binding protein production by individual tissues could alter independently their own sensitivity to circulating $\mathrm{GH}$. Serum levels of GH-binding protein also could be regulated under certain physiological conditions, thus altering GH action in the whole animal. These effects could result in a complex pattern of GH activity in vivo that is not determined merely by serum levels of the hormone. Several other examples of soluble forms of cell-surface receptors have been demonstrated in vivo, for example, nerve growth factor receptor (DiStefano and Johnson 1988), transferrin receptor (Beguin et al. 1988), IGF-II/mannose 6-phosphate receptor (MacDonald et al. 1989), N-CAM (Gower et al. 1988), IgM (Gough 1987), and MHC antigens (Gussow and Pleogh 1987). Apart from immunoglobulins, the functions of these soluble forms of cell-surface receptors have not been identified, although the mechanism of production of several has been shown to be alternative splicing (Gough 1987; 
Table 1. Localization of ${ }^{125}$ I-labeled bovine growth hormone binding activity in transfected COS-7 cells

\begin{tabular}{lcc}
\hline & \multicolumn{2}{c}{ 125I-bGH-binding activity found in } \\
\cline { 2 - 3 } Plasmid & $\begin{array}{l}\text { whole cells } \\
(\%)\end{array}$ & $\begin{array}{l}\text { medium } \\
(\%)\end{array}$ \\
\hline RatR1 & 77 & 23 \\
RatBP1 & 4 & 96 \\
\hline
\end{tabular}

COS-7 cells were transfected with either pSVLRatR1 or pSVLRatBP1 and fractions (whole cells and medium) were prepared. Specific binding was determined by incubation in the presence or absence of excess unlabeled bovine GH. Bound and free were separated as described in Materials and methods. Specific binding is expressed as a percentage of total binding for each plasmid (whole cells + medium).

Gussow and Pleogh 1987; Gower et al. 1988). Clearly, soluble forms of receptors could have an important role in the regulation of ligand action in vivo.

\section{Materials and methods}

\section{Isolation of cDNA clones}

A rat liver cDNA library cloned into bacteriophage $\lambda g t 11$ (purchased from Clontech, Palo Alto, California) was screened with two oligonucleotide probes designed from the published sequence of the rabbit GH receptor (Leung et al. 1987). The oligonucleotides designated GHR1 and GHR2 have the following sequence: 5'-GAGCCCAAATTCACCAAGTGCCGTTCACCTGAACTAGAGAC-3' $(148$ to 188$)$ and $5^{\prime}$-GCACCTTCTCAGCTCAGCAATCCAAATTCACTGGCAAAC-3' (141) to 1449), respectively. The oligonucleotides were end-labeled with $\left[\gamma^{-32}\right.$ P $]$ ATP and polynucleotide kinase. Hybridization was carried out in Church buffer (Church and Gilbert 1987) at $60^{\circ} \mathrm{C}$. Church buffer is $7 \%$ SDS, $0.5 \%$ bovine serum albumin, $0.5 \mathrm{M}$ $\mathrm{Na}_{2} \mathrm{HPO}_{4}(\mathrm{pH} 7.2)$, and $1 \mathrm{~mm}$ EDTA. The filters were washed in $1 \times$ SSC and $0.1 \%$ SDS at $55^{\circ} \mathrm{C}$. GHR 1 gave 19 positives. Two positives, designated RatBP1 and RatBP2, were selected for further analysis. No positives were obtained with GHR2. Using GHR2 oligonucleotide as probe, a rabbit liver GH receptor cDNA was isolated from a rabbit liver cDNA library cloned into bacteriophage $\lambda g t 11$. The library was constructed using random priming as described (Gübler and Hoffman 1983). A

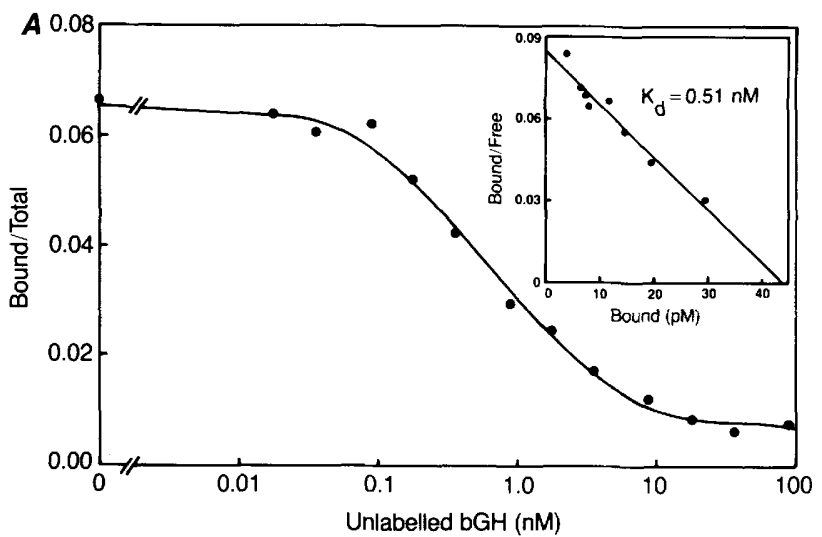

500-nucleotide EcoRI fragment, corresponding to the intracellular domain of the rabbit GH receptor, was labeled with $\left[\alpha{ }^{32} \mathrm{P}\right] \mathrm{dCTP}$ by random priming (Feinberg and Vogelstein 1983a,b) and was used to screen the rat liver cDNA library. Two positives, designated RatR2 and RatRl, were selected for further analysis. All of the cDNAs were excised from bacteriophage $\lambda$ gtll and subcloned into pGEM3 (Promega Biotec, Madison, Wisconsin). Complete DNA sequence analysis of RatBP1 and RatR1 by use of the dideoxy chain-termination method (Sanger et al. 1977) was determined by subcloning appropriate restriction fragments into pGEM3. Complete sequence data on both strands were obtained. RatRl contains two nonrelated cDNAs that were ligated during the cloning process. The extreme $5^{\prime}$ end of RatRl corresponds to rat apolipoprotein cIII. These data are not illustrated in Figure 1. The beginning of RatR1, which is depicted in Figure 1 and all subsequent figures, was determined by comparison to both the $5^{\prime}$ sequence of RatR2 and the known sequence of apolipoprotein cIII. A relevant hybrid of RatR2 and RatR1 was used for sequence determination as shown in this figure and for all subsequent experiments.

\section{RNA preparation and analysis}

Cytoplasmic RNA was prepared from adult (7 weeks) male or female rat liver tissue as described (Favaloro et al. 1980) and poly $(A)^{+}$RNA was selected by chromatography on oligo(dT) cellulose (Maniatis et al. 1982). For Northern analysis, $3 \mu \mathrm{g}$ of poly $(\mathrm{A})+$ RNA was electrophoresized in a $1 \%$ agarose gel that contained formaldehyde and was transferred to nylon (Nytran, Schleicher \& Schuell) as described (Derman et al. 1981). The membranes were prehybrized and hybridized in Church buffer. The blots were washed in $0.2 \times$ SSC and $0.1 \%$ SDS at $65^{\circ} \mathrm{C}$. Blots were exposed at $-70^{\circ} \mathrm{C}$ to $\mathrm{X}$-ray film with an intensifying screen. All probes were labeled with $\left[\alpha^{-32} \mathrm{P}\right] \mathrm{dCTP}$ by random priming (Feinberg and Vogelstein 1983a,b). Probe A is a HindIII fragment that corresponds to nucleotides 91-382 of RatR1. Probe B is a BgIII to HindIII fragment that corresponds to nucleotides 936-1674 of RatR1. Probe C is an AvaII to EcoRI fragment that corresponds to nucleotides 787-944 of RatBPl.

The S1 nuclease probes were constructed as follows. The BP probe was prepared from a HindIII subclone of RatBPl, called RatBP1-5, extending from position 382 to position 944 of the cDNA. RatBP1-5 was cut with BamHI at position 500 and in cubated with $\left[\alpha^{-32}\right.$ P]dGTP $(3000 \mathrm{Ci} / \mathrm{mmole})$ and the Klenow

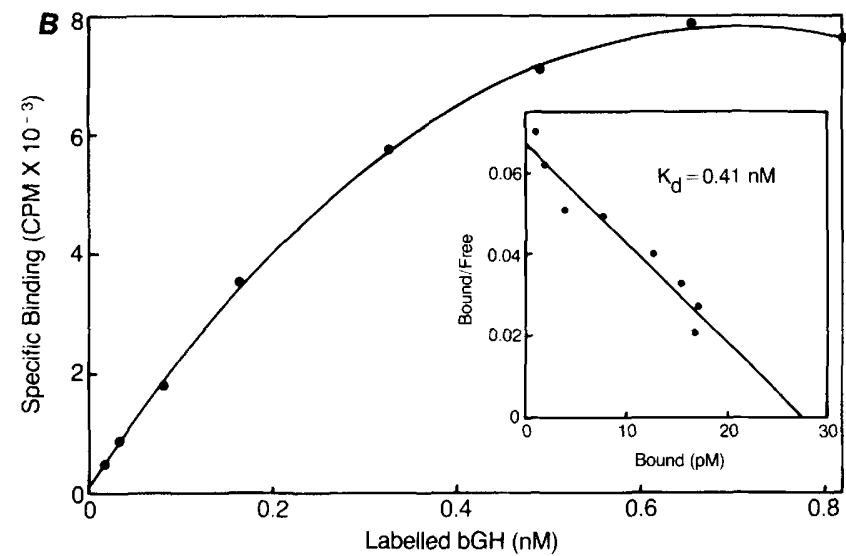

Figure 4. Binding of ${ }^{125} \mathrm{I}$-labeled bovine $\mathrm{GH}$ to rat $\mathrm{GH}$ receptor and rat serum GH-binding protein expressed in COS-7 cells. $(A)$ Competition binding curve of the rat $\mathrm{GH}$ receptor cDNA expressed in COS-7 cells. A constant amount of ${ }^{125} \mathrm{I}-\mathrm{lab}$ - 1 ed bovine $\mathrm{GH}$ was incubated with increasing amounts of unlabeled bovine GH. $(B)$ Saturation binding curve of the rat GH-binding protein expressed in COS-7 cells. Scatchard plots are shown in $A$ and $B$ (inserts). 
fragment of Escherichia coli DNA polymerase I. After extraction, the mixture was cleaved with KpnI, which cuts in the polylinker 20 nucleotides $3^{\prime}$ to position 944 . Thus, this 458-nucleotide fragment was 3 '-end-labeled at position 501. The GHR probe was prepared from RatR1-19, which is a subclone of RatR1 from HindIII, at position 392, to BgIII, at position 936. RatR1-19 was cut with BamHI, at position 500, and EcoRI (in the polylinker) and then incubated with $\left[\alpha-{ }^{32} \mathrm{P}\right] \mathrm{dGTP}(3000 \mathrm{Ci} /$ mmole) and the Klenow fragment of $E$. coli DNA polymerase I. The 463-nucleotide fragment similarly was 3 '-end-labeled at position 501. S1 nuclease mapping was performed as described (Favaloro et al. 1980; Maniatis et al. 1982). The probe was hybridized with or without $3 \mu \mathrm{g}$ of poly $(\mathrm{A}))^{+}$mRNA from adult female rat liver. The protected fragments were analyzed on a $4 \%$ acrylamide-urea gel and exposed to X-ray film at $-70^{\circ} \mathrm{C}$ with an intensifying screen.

\section{Expression of cDNAs in COS-7 cells and ligand binding studies}

RatBPl and RatRl cDNAs were cloned into the SmaI site of pSVL (Pharmacia). These plasmids and pSVL were transfected into COS-7 cells by the standard calcium phosphate precipitation technique (Gorman et al. 1983). After transfection, the cells were kept in Dulbecco's modified Eagle's medium containing $10 \%$ fetal calf serum. At two days post-transfection, the medium was removed and the cells were washed with PBS. A serum free medium, MCDB 201 medium, complete with trace elements and containing L-glutamine and $30 \mathrm{mM}$ HEPES, originally designed for clonal growth of chicken embryo fibroblasts (Sigma), was added, and the cells were incubated for an additional day. At harvest, the medium was removed and saved. The cells were scraped into PBS and washed twice with PBS. Cell-associated GH-binding activity was measured by incubation of the cells in PBS containing $0.5 \%$ bovine serum albumin, $10 \mathrm{mM} \mathrm{MgCl}_{2}$ with $40,000 \mathrm{cpm}$ of ${ }^{125}$ I-bovine $\mathrm{GH}(50-60 \mu \mathrm{Ci} /$ $\mu \mathrm{g} /$ and increasing amounts of unlabeled bovine $\mathrm{GH}$. Bound and free fractions were separated by centrifugation. GH-binding activity in the medium was detected by incubating in $0.5 \%$ BSA and $10 \mathrm{mM} \mathrm{MgCl}_{2}$ with increasing amounts of ${ }^{125}$ I-bovine $\mathrm{GH}$. Bound and free fractions were separated by chromatography on a Sephacryl S-200 column as described (Ymer and Herington 1985; Baumann et al. 1986; Herington et al. 1986).

\section{Acknowledgments}

We thank the members of the Molecular and Cellular Biology Group for comments and American Cyanamid for continued support. We are grateful to Carole Kamrad for her patience and skill in the preparation of this manuscript.

\section{References}

Barnard, R. and M.J. Waters. 1986. Serum and liver cytosolic growth hormone-binding proteins are antigenically identical with liver membrane receptor types 1 and 2 . Biochem. I. 237: 885-892.

Baumann, G., M.W. Stolar, K. Amburn, C.P. Barsano, and B.C. DeVries. 1986. A specific growth hormone-binding protein in human plasma: Initial characterization. J. Clin. Endo. Metab. 62: 134-141.

Baumann, G., M.A. Shaw, and R.J. Winter. 1987. Absence of the plasma growth hormone binding protein in Laron-type dwarfism. J. Clin. Endo. Metab. 65: 814-816.

Baumann, G. and M.A. Shaw. 1988. Immunochemical simi- larity of the human plasma growth hormone-binding protein and the rabbit liver growth hormone receptor. $B B R C$ 152: $573-578$.

Beguin, Y., H.A. Huebers, B. Josephson, and C.A. Finch. 1988. Transferrin receptors in rat plasma. Proc. Natl. Acad. Sci. 85: $637-640$.

Birnstiel, M.L., M. Busslinger, and K. Strub. 1985. Transcription termination and 3 ' processing: The end is in site! Cell 41: 349-359.

Church, E.M. and W. Gilbert. 1984. Genomic sequencing. Proc. Natl. Acad. Sci. 81: 1991-1995.

Daughaday, W.H. and B. Trivedi. 1987. Absence of serum growth hormone binding protein in patients with growth hormone receptor deficiency (Laron dwarfism). Proc. Natl. Acad. Sci. 84: 4636-4640.

Derman, E., K. Krauter, L. Walling, C. Weinberger, M. Kay, and J.E. Darnell Jr. 1981. Transcriptional control in the production of liver-specific mRNAs. Cell 23: 731-739.

DiStefano, P.S. and E.M. Johnson Jr. 1988. Identification of a truncated form of the nerve growth factor receptor. Proc. Natl. Acad. Sci. 85: 270-274.

Eshet, R., Z. Laron, A. Pertizelan, I.R. Amon, and M. Dintzman. 1984. Defect of human growth hormone receptors in the liver of two patients with Laron-type dwarfism. Israel $/$. Med. Sci. 20: 8-13.

Favaloro, J., R. Triesman, and R. Kamen. 1980. Transcription maps of polyoma virus specific RNAs: Analysis by two dimensional nuclease S1 gel mapping. Methods Enzymol. 65: $718-749$.

Feinberg, A.P. and B. Vogelstein. 1983a. A technique for radiolabelling DNA restriction endonuclease fragments to high specific activity. Anal. Biochem. 132: 6-13.

- 1983b. A technique for radiolabelling DNA restriction endonuclease fragments to high specific activity. Anal. Biochem. 137: 266-267.

Gluzman, Y. 1981. SV40-Transformed simian cells support the replication of early SV40 mutants. Cell 23: 175-182.

Gorman, C., R. Padmanabhan, and B.H. Howard. 1983. High efficiency DNA mediated transformation of primate cells. Science 221: 551-553.

Gough, N. 1987. Putting a stop in the immunoglobulin message. Trends Genet. 3: 236-239.

Gower, H.J., C.W. Barton, V.L. Elsom, J. Thompson, S.E. Moore, G. Dickson, and F.S. Walsh. 1988. Alternative splicing generates a secreted form of N-CAM in muscle and brain. Cell 55: 955-964.

Gübler, U. and B.J. Hoffman. 1983. A simple and very efficient method for generating cDNA libraries. Gene 25: 263-269.

Gussow, D. and H. Pleogh. 1987. Soluble class I antigens: A conundrum with no solution. Immunal. Today 8: 220-222.

Herington, A.C., S. Ymer, and J. Stevenson. 1986. Affinity purification and structural characterization of a specific binding protein for human growth hormone in human serum. $J$. Clin. Invest. 77: 1817-1823.

Hughes, J.P. and H.G. Friesen. 1985. The nature and regulation of the receptors for pituitary growth hormone. Annu. Rev. Physiol. 47: 469-482.

Kyte, J. and R.F. Doolittle. 1982. A simple method for displaying the hydropathic characteristics of a protein. I. Mol. Biol. 157: 105-132.

Leung, D.W., S.A. Spencer, G. Cachianes, R.G. Hammonds, C. Collins, W.J. Henzel, R. Barnard, M.J. Waters, and W.I. Wood. 1987. Growth hormone receptor and serum binding protein: purification, cloning and expression. Nature 330: $537-543$.

Maniatis, T., E. Fritsch, and J. Sambrook. 1982. Molecular 
cloning: A laboratory manual. Cold Spring Harbor Laboratory, Cold Spring Harbor, New York.

MacDonald, R.G., M.A. Tepper, K.B. Clairmont, S.B Perregaux, and M.P. Czech. 1989. Serum form of the rat insulin-like growth factor II/Mannose 6-phosphate receptor is truncated in the carboxyl terminal domain. J. Biol. Chem. 264: 32563261.

Maes, M., R. DeHertogh, P. Watrin-Granger, and J.M. Ketelslegers. 1983. Ontogeny of liver somatotropic and lactogenic binding sites in male and female rats. Endocrinology 113: 1325-1332.

Sanger, F., S. Nicklen, and A.R. Coulson. 1977. DNA sequencing with chain-terminating inhibitors. Proc. Natl. Acad. Sci. 74: 5463-5467.

Smith, W.C., D.I.H. Linzer, and F. Talamantes. 1988. Detection of two growth hormone receptor mRNAs and primary translation products in the mouse. Proc. Natl. Acad. Sci. 85: 9576-9579.

Spencer, S.A., R.G. Hammonds, W.J. Henzel, H. Rodriguez, M.J. Waters, and W.I. Wood. 1988. Rabbit liver growth hormone receptor and serum binding protein purification, characterization and sequence. J. Biol. Chem. 263: 7862-7867.

Templeton, D. and W. Eckhart. 1984. Construction and analysis of mutations of the polyoma medium $\mathrm{T}$ antigen: Effects on cell transformation. Mol. Cell. Biol. 4: 817-825.

Trivedi, B. and W.H. Daughaday. 1988. Release of growth hormone binding protein from IM-9 lymphocytes by endopeptidase is dependent on sulfydryl group inactivation. Endocrinology 123: 2201-2206.

Ymer, S.I. and A.C. Herington. 1985. Evidence for the specific binding of growth hormone to a receptor like protein in rabbit serum. Mol. Cell. Endocrinol. 41: 153-161. 




\section{The growth hormone-binding protein in rat serum is an alternatively spliced form of the rat growth hormone receptor.}

W R Baumbach, D L Horner and J S Logan

Genes Dev. 1989, 3:

Access the most recent version at doi:10.1101/gad.3.8.1199

References This article cites 32 articles, 11 of which can be accessed free at:

http://genesdev.cshlp.org/content/3/8/1199.full.html\#ref-list-1

License

Email Alerting

Service

Receive free email alerts when new articles cite this article - sign up in the box at the top right corner of the article or click here.

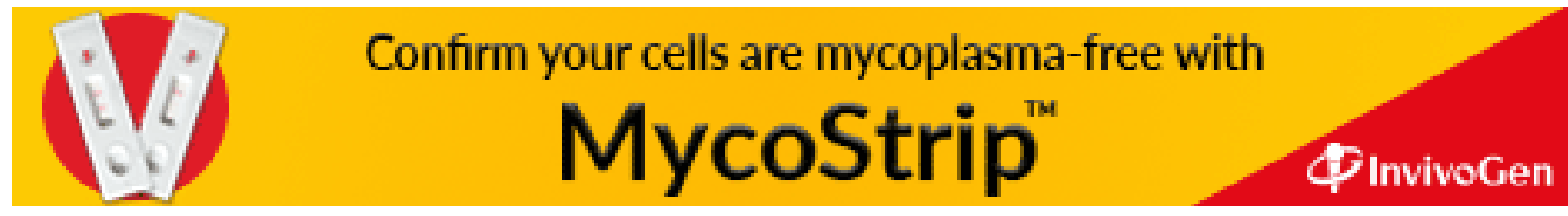

